\title{
Decrease In The Number Of People Taking The CPA Exam Not Due To The 150-Hour Requirement
}

Teresa R. Metinko, Latrobe Steel Company, USA Dahli Gray, Walden University, USA

\begin{abstract}
This paper reports the results of a study that examined the association of the 120/150-hour education requirement with the number of CPA exam candidates during 1998 and 2008. Data gathered from the NASBA Candidate Performance Reports 1999 and 2009 found no relationship between the number of CPA exam candidates and the education requirements in each of the US jurisdictions. Approximately 48\% of the total decline in candidates in 2008 as compared to 1998 occurred in jurisdictions that only required 120 hours of education to sit for the exam in 2008. Approximately $20 \%$ of the total decline occurred in jurisdictions that required 150 hours of education in 2008. The 150-hour requirement is not the cause for the decrease in the number of people taking the CPA exam.
\end{abstract}

Keywords: CPA Exam, 150-hour Rule, Accounting, Graduate Education in Accounting, Continuing Education in Accounting

\section{INTRODUCTION}

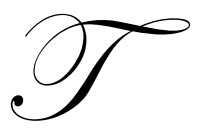

his study provides information about the relationship between the number of people taking the CPA exam and the requirement to have either 120 or 150 hours of education before sitting for the CPA exam or becoming a licensed CPA. Correlation analysis was used to test the significance when comparing and contrasting the number of people taking the CPA exam in jurisdictions that have differing education requirements.

The study examined the relationship between two variables. The first variable, $\mathrm{y}_{\mathrm{i}}$, was the number of people taking the CPA exam in a jurisdiction in year $\mathrm{i}$. The second variable, $\mathrm{x}_{\mathrm{i}}$, was equal to 1 if a state has the 150 hour education requirement to sit for the exam in effect and 0 if it does not. This data were taken from the NASBA publications, Candidate Performance on the Uniform CPA Examination, 1999 and 2009.

The Pearson Product Moment Correlation Coefficient for the entire population ("R") was calculated to determine if there is a linear relationship between the variables, as well as the strength of that relationship for both 1998 and 2008.

The number of people taking the CPA exam in each jurisdiction was compared to the number of people taking the CPA exam in jurisdictions that had the 150-hour requirement in effect during both 1998 and 2008 . The number of exam takers in jurisdictions that required 150 hours of education for licensure prior to 1998, but now let candidates sit for the CPA exam with 120 hours of education during 2008, were compared. The number of exam takers in jurisdictions that only required 120 hours of education for licensure prior to 1998, but have now enacted the 150-hour education requirement, but let candidates sit for the CPA exam with 120 hours of education in 2008, were compared. The number of people taking the CPA exam in jurisdictions that did not have the 150-hour education requirement for licensure in effect during either 1998 or 2008 was compared. The Pearson Product Moment Correlation Coefficient was used to determine if there is any correlation between the 150-hour education 
requirement and the number of people sitting for the CPA exam in these years.

Schroeder and Franz (2004) found that the number of first-time CPA candidates increases in the year before the 150-hour-to-sit requirement was implemented in a jurisdiction and then dropped dramatically in the year the 150-hour-to-sit requirement was enacted, sometimes by as much as $75 \%$ ( p. 66). Billiot, Glandon, and McFerrin (2004) found that although "the accounting profession has no influence over the demographic conditions that impact the number of high school seniors who might be eligible to attend college...[or] ... the macroeconomic conditions that cause unemployment rates to vary over time", there are other factors that they can control ( p. 464). Dresnack and Strieter (2005) studied the effectiveness of the 150-hour requirement as perceived by CPAs working in "public practice $(40 \%)$, industry $(40 \%)$, and not-for-profit, education, government, and retirement $(20 \%)$ " in nine states that had implemented the requirement between 1993 and 1997 (p. 64). "The respondents found little or no benefit from the 150-hour requirement" in regards to entry-level accountants' capabilities (Dresnack \& Strieter, p. 64). Wier, Stone and Hunton's 2005 study found that job performance evaluations were considerably better for holders of master's degrees than for holders of bachelor's-only degrees (p. 96). Allen and Woodland's 2006 study found that "...implementation of the 150-hour requirement is associated with a large decrease (36 percent) in candidates, but little, if any, association with pass rate. Moreland and Angur (2006) showed that in addition to 150hours of education, CPAs still needed actual work experience in order to develop the necessary competencies (p. 12). Carpenter and Stephenson (2006) presented "evidence that the 150-hour educational requirement has substantially reduced the number of candidates sitting for the CPA exam" by as much as 60 percent (p. 124). He concludes that if the trend continues, "CPA salaries should increase...Membership in professional organizations... should decrease. Audit fees should increase and CPA firms should change their mix of employees toward non-CPA staffers" (Carpenter \& Stephenson, 2006, p. 124). Jackson (2006) reported that the 150-hour education requirement resulted in "an increase in the success rate and a decline in the number of the first-time takers of the CPA exam" (p. 111). The increased success rate suggests improved quality of those taking the test for the first time in 150-hour jurisdictions, while the decreased number of candidates results in less CPAs entering the profession (Jackson, 2006, p. 111). According to Elfrink and Woodruff (2008), "American universities graduated 60,390 accounting majors. By 2001-02, the number of new accountants graduating had bottomed out at 44,695. ... By (2003-04), [it] shows a rebound to 53,760" (p. 68). With the adoption of the 150 -hour requirement in many jurisdictions, there are also less CPA exam candidates (Elfrink \& Woodruff, p. 68). Elfrink and Woodruff stated that there were 109,782 candidates for the exam in 2003, which was less than the 113,629 who sat in 1979, even though both years had a similar number of accounting graduates (p. 68). Efforts need to be taken to combat the effects of the 150-hour requirement and other factors contributing to the decline in CPA exam candidates (Elfrink \& Woodruff, p. 71). A study done by Carpenter and Hock (2006) reported on the results of the 150-hour requirement on CPA candidate performance in Florida, New York, and Texas (p. 62). A reduction in the number of new candidates sitting for the exam once the 150-hour requirement was enacted is shown, while the percentage of candidates passing the exam increased (Carpenter \& Hock, 2006, p. 64).

All of the studies mentioned above have a common thread. Each shows a reduction in the number of CPA exam candidates in jurisdictions where the 150 -hour requirement has been enacted. Most of these jurisdictions also show an increase in pass rates during these periods. This study adds to the findings over a longer period of time than any of the prior studies.

The following formula was used to calculate the Pearson Product Moment Correlation Coefficient, "R", for the entire population in 1998 and 2008. This population is made up of the total number of CPA exam takers in all jurisdictions in each of these years, not just a sample:

$\mathrm{R}=[1 / \mathrm{N}] * \Sigma\left\{\left[\left(\mathrm{X}_{\mathrm{i}}-\mu_{\mathrm{X}}\right) / \sigma_{\mathrm{x}}\right] *\left[\left(\mathrm{Y}_{\mathrm{i}}-\mu_{\mathrm{Y}}\right) / \sigma_{\mathrm{y}}\right]\right\}$

where $\mathrm{N}$ is the number of observations in the population, $\Sigma$ is the summation symbol, $\mathrm{X}_{\mathrm{i}}$ is the $\mathrm{X}$ value for observation $\mathrm{i}, \mu_{\mathrm{X}}$ is the population mean for variable $\mathrm{X}, \mathrm{Y}_{\mathrm{i}}$ is the $\mathrm{Y}$ value for observation $\mathrm{i}, \mu_{\mathrm{Y}}$ is the population mean for variable $\mathrm{Y}, \sigma_{\mathrm{x}}$ is the population standard deviation of $\mathrm{X}$, and $\sigma_{\mathrm{y}}$ is the population standard deviation of $\mathrm{Y}$. As calculated for $1998, " \mathrm{R} "=.05$, while "R" $=-.17$ for 2008 . 
During 1998, 116,906 people sat for the CPA exam in the 55 US jurisdictions. Ten years later in 2008, the number of people taking the exam had decreased to 85,391, a difference of 31,515 people, as shown in Table 1 below. This decrease can be attributed to many different factors in addition to the 150 -hour education requirement to sit for the CPA exam and become a licensed CPA.

Table 1: Number of CPA Exam Candidates for All Jurisdictions in 1998 and 2008

\begin{tabular}{|c|c|c|c|c|c|}
\hline 1998 All & $\begin{array}{l}\text { \# of } \\
\text { Candidates } \\
\end{array}$ & 2008 All & $\begin{array}{l}\text { \# of } \\
\text { Candidates } \\
\end{array}$ & $\begin{array}{l}\text { Total Decrease } \\
\text { in all } \\
\text { Jurisdictions }\end{array}$ & $\begin{array}{l}\text { \# of } \\
\text { Candidates } \\
\end{array}$ \\
\hline Jurisdictions & 116,906 & Jurisdictions & 85,391 & 1998-2008 & 31,515 \\
\hline
\end{tabular}

Fourteen US jurisdictions had the 150-hour education requirement to sit for the CPA exam and become licensed in effect during both 1998 and 2008. The number of test takers decreased by 6,314 people in 2008 compared to 1998. This accounted for slightly over $20 \%$ of the total decrease of 31,515 test takers in all jurisdictions in 2008 as compared to 1998, as shown below in Table 2.

Table 2: Jurisdictions with the 150-hour Education Requirement in effect during 1998 and 2008

\begin{tabular}{|c|c|c|c|c|c|c|c|c|}
\hline & 1998 & & & 2008 & & & & Percent of Total \\
\hline$\underline{\text { State }}$ & $\begin{array}{c}\text { \# of } \\
\text { Candidates } \\
\end{array}$ & $\begin{array}{l}\text { Percent } \\
\text { of Total }\end{array}$ & & $\begin{array}{c}\text { \# of } \\
\text { Candidates } \\
\end{array}$ & $\begin{array}{l}\text { Percent } \\
\text { of Total }\end{array}$ & & $\begin{array}{c}\text { 1998-2008 } \\
\text { Difference }\end{array}$ & $\begin{array}{c}\text { decrease in } \\
\text { All Jurisdictions } \\
\end{array}$ \\
\hline$\overline{\mathrm{AL}}$ & 995 & $\overline{0.85 \%}$ & & 623 & $\overline{0.73 \%}$ & & -372 & $1.18 \%$ \\
\hline $\mathrm{AR}$ & 828 & $0.71 \%$ & & 389 & $0.46 \%$ & & -439 & $1.39 \%$ \\
\hline FL & 1,515 & $1.30 \%$ & & 1,569 & $1.84 \%$ & & 54 & $-0.17 \%$ \\
\hline GA & 3,922 & $3.35 \%$ & & 2,962 & $3.47 \%$ & & -960 & $3.05 \%$ \\
\hline KS & 609 & $0.52 \%$ & & 458 & $0.54 \%$ & & -151 & $0.48 \%$ \\
\hline LA & 1,151 & $0.98 \%$ & & 715 & $0.84 \%$ & & -436 & $1.38 \%$ \\
\hline MS & 553 & $0.47 \%$ & & 345 & $0.40 \%$ & & -208 & $0.66 \%$ \\
\hline MT & 402 & $0.34 \%$ & & 475 & $0.56 \%$ & & 73 & $-0.23 \%$ \\
\hline $\mathrm{NE}$ & 677 & $0.58 \%$ & & 306 & $0.36 \%$ & & -371 & $1.18 \%$ \\
\hline $\mathrm{SC}$ & 1,173 & $1.00 \%$ & & 654 & $0.77 \%$ & & -519 & $1.65 \%$ \\
\hline SD & 361 & $0.31 \%$ & & 99 & $0.12 \%$ & & -262 & $0.83 \%$ \\
\hline $\mathrm{TN}$ & 1,292 & $1.11 \%$ & & 1,542 & $1.81 \%$ & & 250 & $-0.79 \%$ \\
\hline TX & 8,218 & $7.03 \%$ & & 5,143 & $6.02 \%$ & & $-3,075$ & $9.76 \%$ \\
\hline UT & 392 & $0.34 \%$ & & 494 & $0.58 \%$ & & 102 & $-0.32 \%$ \\
\hline Total & 22,088 & $18.89 \%$ & Total & 15,774 & $18.47 \%$ & Difference & $-6,314$ & $20.03 \%$ \\
\hline
\end{tabular}

Sources: National Association of State Boards of Accountancy (1999). Candidate performance on the Uniform CPA Examination. Nashville, TN, and National Association of State Boards of Accountancy (2009). Candidate performance on the Uniform CPA Examination: Reports \& commentary on the 2008 CPA Examination. Nashville, TN.

Five US jurisdictions, that later changed their requirements, had the 150-hour education requirement to sit for the CPA exam and become licensed in effect in 1998. Prior to 2008, these five jurisdictions then decreased their requirement to sit for the CPA exam to 120 hours of education, leaving the 150 -hour requirement to become a licensed CPA. This trend was evident in many jurisdictions over the ten years between 1998 and 2008. These jurisdictions experienced a decrease of 1,437 people in 2008 compared to 1998. This decrease was approximately $5 \%$ of the total decrease of 31,515 test takers in 2008 compared to 1998, as shown in Table 3. 
Table 3: Jurisdictions with the 150-hour Education Requirement in effect during 1998, but now allow Candidates to sit with 120 Hours in 2008

\begin{tabular}{|c|c|c|c|c|c|c|c|c|}
\hline \multirow[b]{2}{*}{ State } & \multicolumn{2}{|c|}{1998} & & \multicolumn{2}{|c|}{2008} & & & \multirow{2}{*}{$\begin{array}{c}\text { Percent of Total } \\
\text { decrease in } \\
\text { All Jurisdictions }\end{array}$} \\
\hline & $\begin{array}{c}\text { \# of } \\
\text { Candidates }\end{array}$ & $\begin{array}{l}\text { Percent } \\
\text { of Total }\end{array}$ & & $\begin{array}{c}\text { \# of } \\
\text { Candidates }\end{array}$ & $\begin{array}{l}\text { Percent } \\
\text { of Total }\end{array}$ & & $\begin{array}{l}1998-2008 \\
\text { Difference }\end{array}$ & \\
\hline FL & 1,515 & $1.30 \%$ & & 1,569 & $1.84 \%$ & & 54 & $-0.17 \%$ \\
\hline GA & 3,922 & $3.35 \%$ & & 2,962 & $3.47 \%$ & & -960 & $3.05 \%$ \\
\hline $\mathrm{SC}$ & 1,173 & $1.00 \%$ & & 654 & $0.77 \%$ & & -519 & $1.65 \%$ \\
\hline SD & 361 & $0.31 \%$ & & 99 & $0.12 \%$ & & -262 & $0.83 \%$ \\
\hline $\mathrm{TN}$ & 1,292 & $1.11 \%$ & & 1,542 & $1.81 \%$ & & 250 & $-0.79 \%$ \\
\hline Total & 8,263 & $7.07 \%$ & Total & 6,826 & $7.99 \%$ & Difference & $-1,437$ & $4.56 \%$ \\
\hline
\end{tabular}

Sources: National Association of State Boards of Accountancy (1999). Candidate performance on the Uniform CPA Examination. Nashville, TN, and National Association of State Boards of Accountancy (2009). Candidate performance on the Uniform CPA Examination: Reports \& commentary on the 2008 CPA Examination. Nashville, TN.

Twenty-two US jurisdictions that only required 120 hours of education to sit for the CPA exam and become licensed in 1998 eventually enacted the 150-hour license requirement. Prior to 2008, these jurisdictions changed their requirements. They now require only 120 hours of education to sit for the CPA exam, while retaining the 150hour education requirement in order to become a licensed CPA. There was a decrease of 10,233 people sitting for the CPA exam in 2008 compared to 1998 . This decrease was approximately $32 \%$ of the total decrease of the 31,515 test takers in all jurisdictions for 2008 compared to 1998, as shown below in Table 4.

Table 4: Jurisdictions with the 120-Hour Education Requirement in effect during 1998 now with 150-Hour Education Requirement, but allow Candidates to sit at 120 Hours in 2008

\begin{tabular}{|c|c|c|c|c|c|c|c|c|}
\hline \multirow[b]{2}{*}{ State } & \multicolumn{2}{|c|}{1998} & & \multicolumn{2}{|c|}{2008} & 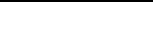 & \multirow[b]{2}{*}{$\begin{array}{l}1998-2008 \\
\text { Difference }\end{array}$} & \multirow{2}{*}{$\begin{array}{c}\text { Percent of Total } \\
\text { decrease in } \\
\text { All Jurisdictions }\end{array}$} \\
\hline & $\begin{array}{c}\text { \# of } \\
\text { Candidates }\end{array}$ & $\begin{array}{l}\text { Percent } \\
\text { of Total }\end{array}$ & & $\begin{array}{c}\# \text { of } \\
\text { Candidates }\end{array}$ & $\begin{array}{l}\text { Percent } \\
\text { of Total }\end{array}$ & & & \\
\hline $\mathrm{AK}$ & 313 & $0.27 \%$ & & 674 & $0.79 \%$ & & 361 & $-1.15 \%$ \\
\hline $\mathrm{AZ}$ & 1,165 & $1.00 \%$ & & 877 & $1.03 \%$ & & -288 & $0.91 \%$ \\
\hline $\mathrm{CT}$ & 1,345 & $1.15 \%$ & & 871 & $1.02 \%$ & & -474 & $1.50 \%$ \\
\hline GUAM & 216 & $0.18 \%$ & & 423 & $0.50 \%$ & & 207 & $-0.66 \%$ \\
\hline HI & 1,456 & $1.25 \%$ & & 364 & $0.43 \%$ & & $-1,092$ & $3.47 \%$ \\
\hline ID & 439 & $0.38 \%$ & & 287 & $0.34 \%$ & & -152 & $0.48 \%$ \\
\hline IA & 1,188 & $1.02 \%$ & & 569 & $0.67 \%$ & & -619 & $1.96 \%$ \\
\hline KY & 1,569 & $1.34 \%$ & & 726 & $0.85 \%$ & & -843 & $2.67 \%$ \\
\hline $\mathrm{ME}$ & 261 & $0.22 \%$ & & 725 & $0.85 \%$ & & 464 & $-1.47 \%$ \\
\hline MA & 2,932 & $2.51 \%$ & & 2517 & $2.95 \%$ & & -415 & $1.32 \%$ \\
\hline MI & 2,724 & $2.33 \%$ & & 1923 & $2.25 \%$ & & -801 & $2.54 \%$ \\
\hline $\mathrm{MN}$ & 1,556 & $1.33 \%$ & & 1462 & $1.71 \%$ & & -94 & $0.30 \%$ \\
\hline MO & 2,494 & $2.13 \%$ & & 1267 & $1.48 \%$ & & $-1,227$ & $3.89 \%$ \\
\hline NJ & 3,263 & $2.79 \%$ & & 2398 & $2.81 \%$ & & -865 & $2.74 \%$ \\
\hline NM & 652 & $0.56 \%$ & & 292 & $0.34 \%$ & & -360 & $1.14 \%$ \\
\hline $\mathrm{NC}$ & 3,151 & $2.70 \%$ & & 1716 & $2.01 \%$ & & $-1,435$ & $4.55 \%$ \\
\hline ND & 374 & $0.32 \%$ & & 242 & $0.28 \%$ & & -132 & $0.42 \%$ \\
\hline RI & 364 & $0.31 \%$ & & 152 & $0.18 \%$ & & -212 & $0.67 \%$ \\
\hline VA & 3,594 & $3.07 \%$ & & 3253 & $3.81 \%$ & & -341 & $1.08 \%$ \\
\hline WA & 2,838 & $2.43 \%$ & & 1920 & $2.25 \%$ & & -918 & $2.91 \%$ \\
\hline WV & 748 & $0.64 \%$ & & 254 & $0.30 \%$ & & -494 & $1.57 \%$ \\
\hline WI & 1,617 & $1.38 \%$ & & 1114 & $1.30 \%$ & & -503 & $1.60 \%$ \\
\hline Total & 34,259 & $29.30 \%$ & Total & 24,026 & $28.14 \%$ & Difference & $-10,233$ & $32.47 \%$ \\
\hline
\end{tabular}

Sources: National Association of State Boards of Accountancy (1999). Candidate performance on the Uniform CPA Examination. Nashville, TN, and National Association of State Boards of Accountancy (2009). Candidate performance on the Uniform CPA Examination: Reports \& commentary on the 2008 CPA Examination. Nashville, TN.

Eight US jurisdictions that did not have the 150-hour education requirement in effect in 1998 still had not enacted it by 2008 . These jurisdictions that never enacted the 150 -hour education requirement experienced a 
decrease of 5,234 test takers in 2008 as compared to 1998. As shown in Table 5, this accounted for approximately $20 \%$ of the total decrease of 31,515 test takers in all jurisdictions during 2008 as compared to 1998.

Table 5: Jurisdictions that Never had the 150-hour Education Requirement in effect in 1998 or 2008

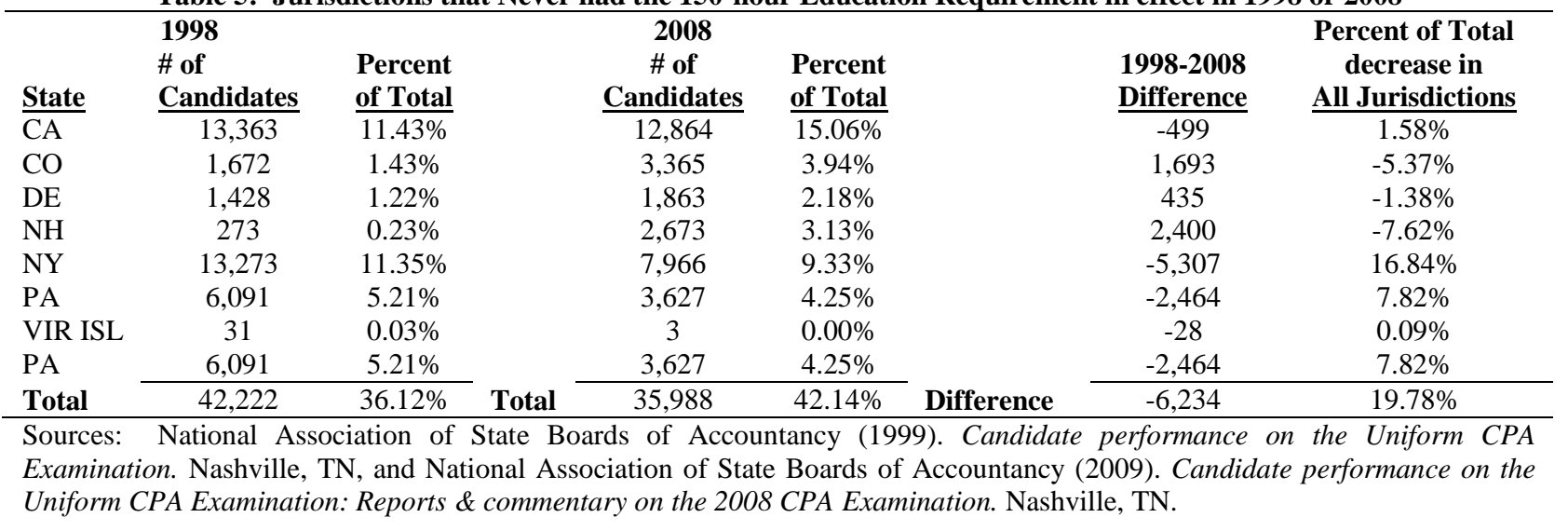

\section{CONCLUSIONS}

There was a dramatic decrease in the number of people who sat for the CPA exam in 2008 as compared to 1998. Approximately $32 \%$ of this decrease can be attributed to the 22 jurisdictions that required only 120 hours of education in 1998, then enacted the 150-hour education requirement, and finally changed to the 120/150-hour education model before 2008. Approximately $20 \%$ of the decrease can be attributed to the 14 jurisdictions that had the 150-hour requirement in effect during both 1998 and 2008. Approximately $11 \%$ of the decrease can be attributed to the five jurisdictions that did not have the 150-hour education requirement in effect in either 1998 or 2008. Finally, approximately 5\% of the total decrease can be attributed to jurisdictions that required 150 hours of education in 1998, but changed to the 120/150-hour education model prior to 2008 .

This shows that $37 \%$ of the total decrease can be attributed to jurisdictions that had adopted the 120/150hour education model prior to 2008. Another $11 \%$ of the total decrease occurred in jurisdictions that never adopted the 150-hour education requirement prior to 2008. Since $48 \%$ of the decrease in CPA exam candidates during 2008, as opposed to 1998 , came from states that only required 120 hours to sit for the exam in 2008 and only $20 \%$ came from states that had the 150-hour requirement in effect in 2008, this would seem to indicate that the education requirement, whether 120 hours or 150 hours, was not the major contributing factor to the overall decrease in CPA exam candidates and does not determine the number of candidates in each jurisdiction.

The Pearson Product Moment Correlation Coefficient for 1998 was only $\mathrm{R}=0.05$, which indicates almost no correlation between the number of CPA exam candidates and the 150-hour education requirement during this year. Even for 2008, while "R" $=-0.17$, indicating a small negative correlation between the number of CPA exam candidates and the 150-hour education requirement, there still is not enough of a correlation to demonstrate a relationship between the two variables. It appears that the decrease in CPA exam candidates in 2008 compared to 1998 should be attributed to many different factors other than just the 150-hour education requirement to sit for the CPA exam and become a licensed CPA.

Schroeder and Franz (2004) believed that other factors were causing the long-term decrease in the number of CPA candidates (p. 66). These factors included the following: "ignorance about a career in accounting; faulty information about the profession; ... negative perceptions of the role of accountants in society; ... decreased salary levels, and the availability of more-attractive career alternatives as other contributors to the declining interest in accounting careers" (p. 66). 
As with any study, certain limitations became apparent during the research process. This study does not take into account the change in the US population, the number of US accounting graduates, or the changes in the CPA exam format that occurred in 1994 and 2004. Addition of these variables might cause different conclusions to be drawn. In the future, these variables could be studied in relation to the 120/150-hour education model. Also, another important area of study that could be addressed is whether the CPA exam should require a higher level of knowledge in order to pass, as a reflection of the changing business environment. Finally, the effect of accounting certifications, such as the Certified Management Accountant designation and the Certified Fraud Examiner designation, could be looked at in relationship to the number of CPA exam candidates.

\section{AUTHOR INFORMATION}

Teresa Metinko works as a consultant with Latrobe Specialty Steel Company in Latrobe, PA through Robert Half Management Recruiting. She earned her Bachelor of Science degree in Business/Accounting from the University of Pittsburgh and her Master of Science in Accounting with an emphasis on Controllership from Strayer University. She is a licensed CPA. She has extensive experience in credit and collection work as well as in public accounting with an emphasis on both income tax and non-profit auditing.

Dahli Gray earned her doctoral degree from the George Washington University, MBA from Portland State University and bachelors degree from Eastern Oregon University. She is a licensed CPA in Maryland and also holds CMA and CFE credentials. She has published in numerous journals, including the Journal of Accounting Research and the Journal of Accountancy. She has presented at conferences in places such as Ireland, England, Japan, Mexico, Canada and throughout the United States. She has had a private consulting firm since the year 2000, which includes teaching part-time for Walden University.

\section{REFERENCES}

1. Allen, A., \& Woodland, A. (2006, August). The 150-hour requirement and the number of CPA exam candidates, pass rates, and the number passing. Issues in Accounting Education, 21(3), 173-193. Retrieved from Business Source Premier database.

2. Billiot, M., Glandon, S., \& McFerrin, R. (2004, November). Factors affecting the supply of accounting graduates. Issues in Accounting Education, 19(4), 443-467. Retrieved from Business Source Premier database.

3. Carpenter, C., \& Hock, C. (2008, June). The 150-hour requirement's effect on the CPA exam. CPA Journal, 78(6), 62-64. Retrieved from Business Source Premier database.

4. Carpenter, C., \& Stephenson, E. (2006, Winter). The 150-hour rule as a barrier to entering public accountancy. Journal of Labor Research, 27(1), 115-126. Retrieved from Business Source Premier database.

5. Department of the Treasury Advisory Committee on the Auditing Profession. (2008, October 6). Final report of the advisory committee on the auditing profession to the Department of the Treasury. Retriever from http://www.treas.gov/offices/domestic-finance/acap/docs/final-report.pdf

6. Dresnack, W., \& Strieter, J. (2005, April). The effectiveness of the 150-hour requirement. CPA Journal, 75(4), 64-66. Retrieved from Business Source Premier database.

7. Dresnack, W., \& Strieter, J. (2006, June). The 150-hour requirement: Perceived impact on quality and image of the profession. CPA Journal, 76(6), 66-69. Retrieved from Business Source Premier database.

8. Elfrink, J., \& Woodruff, G. (2008, February). Recruiting the best and the brightest: The role of accounting societies. CPA Journal, 78(2), 68-71. Retrieved from Business Source Premier database.

9. Jackson, R. (2006, Winter). Post-graduate educational requirements and entry into the CPA profession. Journal of Labor Research, 27(1), 101-114. Retrieved from Business Source Premier database.

10. King, T., Cecil, H., \& Andrews, C. (2009, May). Upcoming changes to the CPA exam. CPA Journal, 79(5), 58-62. Retrieved from Business Source Premier database.

11. Moreland, K., \& Angur, M. (2006, September). The importance of work experience to accountants' professional development. Journal of American Academy of Business, Cambridge, 9(2), 8-13. Retrieved from Business Source Premier database. 
12. National Association of State Boards of Accountancy (1999). Candidate performance on the Uniform CPA Examination. Nashville, TN.

13. National Association of State Boards of Accountancy (2009). Candidate performance on the Uniform CPA Examination: Reports \& commentary on the 2008 CPA Examination. Nashville, TN.

14. Schroeder, N., \& Franz, D. (2004, October). Explaining the decline in CPA candidates. CPA Journal, 74(10), 62-66. Retrieved from Business Source Premier database.

15. Wier, B., Stone, D. \& Hunton, J. (2005, June). Does graduate business education contribute to professional accounting success? Accounting Horizons, 19(2), 85-100. Retrieved from Business Source Premier Database. 
NOTES 